\title{
Risk Management Impact Assessment on the Success of Strategic Investment Projects: Benchmarking Among Different Sector Companies
}

\section{Filip Jovanović ${ }^{1}$, Nenad Milijić ${ }^{2}$, Makedonka Dimitrova ${ }^{3}$, Ivan Mihajlović}

${ }^{1}$ Faculty of Project and Innovation Management, Boze Jankovica 14, 11000 Belgrade, Serbia

${ }^{2}$ University of Belgrade, Technical Faculty in Bor, Management Department, Vojske Jugoslavije 12, 19210 Bor, Serbia

${ }^{3}$ University American College Skopje, Faculty of Business Economics and Management, Blvd. Treta makedonska brigada no.60, Skopje 1000, Macedonia

filip.jovanovic@mozzartbet.com,nmilijic@tf.bor.ac.rs,dimitrova@uacs.edu.mk, imihajlovic@tf.bor.ac.rs

Abstract: The paper explores the impact of the main elements of the strategic investment projects management process in South East Europe (SEE), on achieving project objectives. The impact of different projects elements on the project's risk management process was also addressed. The initial hypotheses are based on literature review in the field. The proposed hypotheses were tested by the SEM (Structural Equation Modeling) methodology on a sample of 311 strategic investment projects in Serbia, Bosnia and Herzegovina as well as Macedonia. The strategic projects were analyzed in companies across various business sectors thus the obtained results represent a benchmark of risk factors' significance according to the project team members and managers. The benchmarking of risk factors significance was conducted by using the PROMETHEE - GAIA methodology. The results verify the adequacy of the hypothetical framework.

\section{Introduction}

Strategic projects (SP) are of great significance for organizations, as they enable environment for realization of strategic objectives. The SP may vary from major investment projects, such as, construction of a new factory or plant, introduction 
of modern technology, improvement of energy efficiency etc., to somewhat smaller projects such as information system introduction, development and implementation of a new organizational structure, quality system introduction or similar.

Asrilhant et al. suggested that the strategic projects are necessary when an organization strives to achieve its long-term objectives and development [1]. In this respect, Schoemaker defines the strategic projects as a manner of implementation and realization of a sound organizational vision [2]. Moreover, SPs are connected to the main investments of the companies and often bear considerable risk and uncertainty, intangible benefits and enable attractive longterm financial benefit $[3,4]$.

The strategic project management process helps achieve the projects' successful implementation, including the financial and the non-financial outcomes, as well as, the benefits. Strategic project management includes two primary phases: the evaluation phase and the monitoring phase [5]. The evaluation phase includes development, planning and the evaluation of the strategic projects as well as the project approval. The strategic projects' monitoring phase envisages the project management, the control and possible adaptation processes in case of necessity [1]. Efficient strategic project management may be achieved if the responsible project manager and the project team perform in accordance with the evaluation and monitoring phase requirements; all based on the predefined influence elements [6]. The process involves application of contemporary methods and techniques necessary to achieve efficient management of the strategic projects [7]. In practice, strategic investment projects most frequently apply the following techniques for their evaluation and monitoring: the return on investment, the net present value, the internal rate of return, the repayment period, the cost benefit analysis, the sensitivity analysis, the decision tree, the risk analysis, the forecasting methods, the game theory, the simulation etc. [1]. Selection process of the methods and techniques to be used in the strategic project management process involves prior analysis and assessment to which extend certain methods and techniques would be applied, if applicable at all [8].

The evaluation and the forecasting of future undertakings, processes and activities are accompanied by uncertainty and risk. Some future project settings might bear risk that could lead to negative and in rare cases positive impact on the project implementation [9]. This is the reason that the project management process entails appropriate project risk management. According to Kerzner, the risk management is an action or an exercise for dealing with risk [10]. The project risk management includes several related actions, such as the risk planning, the identification and analysis of risk events, the development of strategies for risk handling and monitoring, all oriented towards the project success [11]. Successful risk control and management in the strategic investment projects may lead towards the successful projects' implementation. The level of success may be estimated by application of an appropriate criterion [12]. 
This research paper focuses on the strategic investment projects' (SIP) management processes in the companies from the industrial and the non-industrial sectors in South-Eastern Europe (SEE), in particular from Serbia, Macedonia and Bosnia and Herzegovina. Research results from all three countries were analyzed simultaneously. We can explain this decision based on the similarity of all three countries. Namely, not long ago they were Member States of one country, Yugoslavia. Even today, political, economic, social and technological factors do not differ much in all three environments and therefore, we assumed that there should not be much differences in the responses. This research endeavor targets the risk management process, primarily in terms of understanding the effective management process at SIP. Therefore, the objective of this paper is to analyze the impact of the main elements of the risk management processes at SIP in SEE on the achievement of the project goals as well as the impact of the project elements on the risk management process. The importance of the risk factors, were determined, by benchmarking, in accordance with the opinion of the project managers and team members operating across different sectors.

\section{Theoretical Framework and Research Hypotheses}

The research framework of this work was preceded by extensive analysis of the available literature in the field of SIP risk management. Numerous recently published research papers pointed out to the relationship between the appropriate methods for the risks analysis and assessment based on the factors of significance for the decision makers, for evaluation of the overall success of SIP [13, 14, and 15]. Therefore, we have defined the first research hypothesis of this paper as follows:

H1: The application of the methods for risk analysis and assessment is directly related to the risk factors significant for the success of the company's projects

Given the significant relationship between the methods used for the analysis and assessment of risks and the risk factors that are primarily manageable [16, 17, 18], we have defined the second research hypothesis as follows:

H2: The application of methods for risk analysis and assessment is directly related to risk factors of significance for project risk management

The contemporary literature dealing with project risk management identifies that the analysis of risk factors is significant for the project's success and their relationship with the risk management success $[19,20,21]$. The following hypothesis is based on the previous findings:

H3: The risk factors of significance for the success of a company's projects influence the risk management results 
Analysis of the factors significant for risk management and their relationship with the success of risk management is featured in a many research publications as well $[22,23,24]$. Based on results of the authors of the aforementioned papers, the following hypothesis is proposed as:

H4: The factors of significance for project risk management affect the risk management results

On the other hand, some of the latest papers dealing with the correlation of elements of significance to SIP control, and the applied methods for project management $[25,26,27]$, have led to the proposal of the following hypothesis:

H5: The elements of significance for the control of the strategic investment project are directly correlated to the methods for strategic investment project management

Apart from that, numerous authors emphasize that the applied methods for SIP management are directly related to a significant criteria for measuring the project success $[28,29,30]$. Therefore, the following hypothesis is further defined as:

H6: The methods for strategic investment project management are directly correlated to the main criteria for measuring project success

In addition to the six research hypotheses, the following statements would be considered axioms, since they are widely accepted in theory and practice $[9,31$, $32,33]$.

A1: The results of the project risk management affect the results of the strategic investment project management

A2: The main criteria for measuring the project success affect the results of the strategic investment project management

\section{Sample and the Data Collection}

The research objective of this paper is to understand the extent to which the risk management process of SIP may be characterized by a set of elements, set forth by the project managers as the most significant ones and which are in accordance with the wide range of data available in the literature related to the topic. The identified elements of significance were then grouped in several groups of research questions. The data collection in this particular research used the questionnaire based methodology [1, 31].

The questionnaire consisted of two parts. The first part consisted of 10 (ten) control questions of a demographic character relevant to the surveyed sample (project-oriented companies, respondents and projects). The second part of the 
questionnaire featured 42 questions in the field of risk management and significant factors for SIP management, all divided into appropriate groups defined in accordance to proposed hypothesis, as presented in the Appendix 1. Based on the questionnaire, the opinions of the project managers on the importance of the methods for analysis and assessment of project risk were reviewed ( $1^{\text {st }}$ group of questions - G1), along with risk factors having the greatest impact on the projects' success $\left(2^{\text {nd }}\right.$ group of questions $\left.-\mathrm{G} 2\right)$, then the most significant factors for the project risk management ( $3^{\text {rd }}$ group of questions $-\mathrm{G} 3$ ), the elements significant in the process of SIP control ( $4^{\text {th }}$ group of questions $\left.-\mathrm{G} 4\right)$, the methods for the evaluation and control of SIPs ( $5^{\text {th }}$ group of questions $\left.-\mathrm{G5}\right)$, as well as the main criteria for measuring the success of SIPs $\left(6^{\text {th }}\right.$ group of questions - G6). The impact of each of these groups of factors on the achieved results of project risk management (Key Question 1 - Q1), as well as the success of management of SIPs of the investigated companies (Key Question 2-Q2) were then analyzed.

The Likert scale was used to measure the different levels of significance, where 1 represents the lowest significance (I absolutely disagree) and 5 represent the highest significance (I absolutely agree). Also, certain questions were of a dichotomous character (yes/no). In order to collect relevant data, project managers and project team members were sampled, in particular those in charge for SIP management or those involved with SIP on frequent basis. A total of 400 questionnaires were sent to potential respondents, 311 of which, were fully completed within the stipulated deadline from Serbia, Bosnia and Herzegovina and Macedonia. A relatively high response rate was achieved, owing to the persistence and the direct contact between the researchers of this paper and the surveyed managers and employees. Employees-non-managers were also included in the research, with the condition that they were engaged in the project teams of the company. Detailed demographic indicators of the companies are presented in Table 1.

Table 1

Profiles of companies, respondents and projects

\begin{tabular}{|l|l|l|l|l|}
\hline Characteristics & $N$ & $\%$ \\
\hline $\begin{array}{l}\text { Company } \\
(N=311)\end{array}$ & Field of the company & IT & 50 & 16.08 \\
\cline { 3 - 5 } & Finance & 13 & 4.18 \\
\cline { 3 - 5 } & Energy sector & 29 & 9.32 \\
\cline { 3 - 5 } & Public administration & 31 & 9.97 \\
\cline { 3 - 5 } & Traffic & 13 & 4.18 \\
\cline { 3 - 5 } & Education & 49 & 15.76 \\
\cline { 3 - 5 } & Scientific-research & 71 & 22.83 \\
\cline { 3 - 5 } & Other & 55 & 17.68 \\
\cline { 3 - 5 } & \multirow{2}{*}{$\begin{array}{l}\text { Number of } \\
\text { employees }\end{array}$} & $<10$ & 57 & 18.33 \\
\cline { 3 - 5 } & & $11-50$ & 102 & 32.80 \\
\cline { 3 - 5 } & $51-250$ & & 38.91 \\
\hline
\end{tabular}




\begin{tabular}{|c|c|c|c|c|}
\hline & & $251-1000$ & 31 & 9.96 \\
\hline & & $>1000$ & 0 & 0 \\
\hline \multirow{27}{*}{$\begin{array}{l}\text { Respondent } \\
(N=311)\end{array}$} & \multirow[t]{4}{*}{ Age } & $<29$ & 58 & 18.65 \\
\hline & & $30-44$ & 81 & 26.04 \\
\hline & & $45-54$ & 65 & 20.90 \\
\hline & & $>55$ & 107 & 34.41 \\
\hline & \multirow{4}{*}{$\begin{array}{l}\text { Years spent in the } \\
\text { company }\end{array}$} & $<5$ & 172 & 55.31 \\
\hline & & $6-15$ & 89 & 28.62 \\
\hline & & $16-25$ & 16 & 5.14 \\
\hline & & $>26$ & 34 & 10.93 \\
\hline & \multirow[t]{4}{*}{ Years of service } & $<5$ & 75 & 24.12 \\
\hline & & $6-15$ & 82 & 26.37 \\
\hline & & $16-25$ & 29 & 9.32 \\
\hline & & $>26$ & 125 & 40.19 \\
\hline & \multirow[t]{6}{*}{ Level of education } & $\begin{array}{l}\text { Secondary vocation. } \\
\text { educ. }\end{array}$ & 31 & 9.97 \\
\hline & & High education & 41 & 13.18 \\
\hline & & Higher education & 17 & 5.47 \\
\hline & & HE - Master & 82 & 26.37 \\
\hline & & MA & 21 & 6.75 \\
\hline & & $\mathrm{PhD}$ & 119 & 38.26 \\
\hline & \multirow[t]{5}{*}{ Field of education } & Technical-technological & 151 & 48.55 \\
\hline & & Legal-economics & 49 & 15.76 \\
\hline & & Social-humanistic & 81 & 26.04 \\
\hline & & Natural- mathematics & 12 & 3.86 \\
\hline & & Other & 18 & 5.79 \\
\hline & \multirow{4}{*}{$\begin{array}{l}\text { Position in the } \\
\text { company }\end{array}$} & Top manager / director & 123 & 39.55 \\
\hline & & Middle management & 42 & 13.50 \\
\hline & & $\begin{array}{lll}\begin{array}{l}\text { Operational level of } \\
\text { management }\end{array} & \\
\end{array}$ & 77 & 24.76 \\
\hline & & Employees & 69 & 22.19 \\
\hline \multirow{10}{*}{$\begin{array}{l}\text { Project } \\
(N=311)\end{array}$} & \multirow[t]{6}{*}{ Type of projects } & ICT & 41 & 13.18 \\
\hline & & $\mathrm{R} \& \mathrm{D}$ & 34 & 10.93 \\
\hline & & Construction & 17 & 5.47 \\
\hline & & Public administration & 29 & 9.32 \\
\hline & & Scientific-research & 83 & 26.69 \\
\hline & & Other & 107 & 34.41 \\
\hline & \multirow{4}{*}{$\begin{array}{l}\text { Duration of project } \\
\text { implementation }\end{array}$} & $<6$ months & 69 & 22.19 \\
\hline & & 6 month -2 years & 213 & 68.49 \\
\hline & & $2-5$ years & 29 & 9.32 \\
\hline & & $>5$ years & 0 & 0 \\
\hline
\end{tabular}




\section{Results and Discussion}

In the following text, the results of the data analysis are presented, in order to identify the relationship among elements of SIPs, as outlined in the initial hypothetical framework. Subsequent to the data entry into a database, we have proceeded to data analysis using the corresponding statistical analysis tools. The statistical analysis included the measurement of adequacy of the whole sample and the validation of the data structure. Then the analysis of the reliability of the risk management indicators of SIPs, placed within the appropriate factor groups, was performed along with testing the initial hypothetical frameworks through the application of structural equations modeling. The statistical analysis of the collected data was performed using the software packages SPSS 18.0 and LISREL 8.80 .

\subsection{Measures of the Sampling Adequacy and Structure Validation}

The measure of sampling adequacy analysis was performed by using the KaiserMeyer-Olkin (KMO) and Bartlett tests. Based on the recommendations of other authors, the minimum acceptable value of the Kaiser-Meyer-Olkin indicator is 0.6 [34]. The analysis showed that the coefficient of the Kaiser-Meyer-Olkin (KMO) sampling adequacy test, for the results of the questionnaire conducted in this research, is 0.738 , indicating that the collected data is suitable for the application of factor analysis. Aside from that, the Bartlett test of sphericity shows the importance $\left(\chi^{2}=592.16, p<0.000\right)$, indicating that there are acceptable correlations among items within the measuring instrument, and that the correlation matrix is not a unit matrix [35].

\subsubsection{Correlation Matrix}

The correlations between the six factor groups and the two key questions on risk management of SIPs within the proposed model are presented in Table 2. Based on the results in Table 2, it can be concluded that the majority of coefficients are near or above the value of 0.5 pointing to a significant internal correlation between the listed SIP management factors, and thus the use of factor analysis in further research is justified [36]. Moreover, most of the correlation coefficients have statistical significance at the level of 0.01 . 
Table 2

Internal correlations between 6 factor groups and two key questions of significance for strategic investment project risk management

\begin{tabular}{|l|r|r|r|r|r|r|r|r|}
\hline Coefficient & G1 & G2 & G3 & G4 & G5 & G6 & Q1 & Q2 \\
\hline G1 & 1.000 & & & & & & & \\
\hline G2 & $0.403 * *$ & 1.000 & & & & & & \\
\hline G3 & $0.651^{* *}$ & $0.618^{* *}$ & 1.000 & & & & & \\
\hline G4 & $0.659^{* *}$ & $0.467 * *$ & $0.561^{* *}$ & 1.000 & & & & \\
\hline G5 & $0.781^{* *}$ & 0.173 & $0.446 * *$ & $0.619^{* *}$ & 1.000 & & & \\
\hline G6 & $0.417 * *$ & $0.806^{* *}$ & $0.721^{* *}$ & $0.550^{* *}$ & $0.218^{*}$ & 1.000 & & \\
\hline Q1 & $0.614^{* *}$ & $0.491^{* *}$ & $0.390^{* *}$ & $0.555^{* *}$ & $0.477^{* *}$ & $0.474 * *$ & 1.000 & \\
\hline Q2 & $0.637^{* *}$ & $0.422^{* *}$ & $0.497 * *$ & $0.583^{* *}$ & $0.663 * *$ & $0.474 * *$ & $0.819 * *$ & 1.000 \\
\hline
\end{tabular}

Note: The level of statistical significance $* p<0.05 ; * * p<0.01$

\subsubsection{Factor Analysis}

The factor analysis was performed in order to extract questions that should be kept within the main factors of control and evaluation of SIPs, as well as the analysis and the management of project risks, placed in the groups G1-G6. The relationships between the measured variables are such that their regrouping into smaller sets of variables may be performed, representing a more concise and understandable structure of the examined field [35].

Based on the results of the factor analyses, it was concluded that, in almost all question groups, certain questions should be eliminated from the final model or further divided in the subgroups. Accordingly, for the group G1 - the analyses of the methods for the assessment and analysis of project risks (Appendix 1), the factor analysis revealed that questions 1.1-1.5 should remain in this factor group, while the questions 1.6. - 1.8 should be removed due to the low factor loadings. Similarly, only the questions 2.1, 2.2 and 2.3, from the group G2 - the results of the risk factors having impact on the project success, should remain in this factor group, while the questions 2.4, and 2.5, should be avoided from the following analysis. On the other hand, considering the large number of questions in the group G3, it should be divided into two factors (the subgroups G3.1 and G3.2), with the group G3.1 including the questions 3.1 - 3.3 and 3.5, and the group G3.2 including all other questions. Almost all the questions in the group G4 - elements of significance for SIP evaluation and control, are in the same factor, with the exception of the question 4.5. The questions in the group G5 - the methods of SIP evaluation and control are one-dimensional, as all of them should remain in just one factor, according to their high factor loadings. The questions in the group G6 - the criteria for measuring SIP success should all remain within one factor, except for the question 6.6, which should be removed from the further analysis. The accuracy of such segmentation of the questions, resulting after the factor 
analysis, was verified using the analysis of reliability of the listed grouped indicators of SIP risk management, presented in the following text.

\subsection{Analysis of the Reliability of SIP Risk Management Indicator Factors}

The evaluation of the internal consistence of the concentration of questions into factors of the indicators of SIP risk management, resulting from the factor analysis was performed by using the Cronbach alpha, the Spearman-Brown and the $\Omega$ tests [37]. According to these tests, presented in Table 3, values of the Cronbach $\alpha$, the Spearman-Brown and the $\Omega$ coefficient higher than 0.70 , represent a good enough internal consistency to enable accurate modeling of the questionnaire results within the surveyed population [38].

Table 3

Coefficients of internal consistency of the final groups of questions (after the factor analysis)

\begin{tabular}{|l|c|c|c|c|}
\hline $\begin{array}{l}\text { Question } \\
\text { groups }\end{array}$ & $\begin{array}{c}\text { Number of } \\
\text { questions } \\
\text { within a group }\end{array}$ & $\begin{array}{c}\text { Cronbach } \alpha \\
\text { coefficient }\end{array}$ & $\begin{array}{c}\text { Spearman- } \\
\text { Brown } \\
\text { coefficient }\end{array}$ & $\Omega$ coefficient \\
\hline G1 & 5 & 0.851 & 0.835 & 0.858 \\
\hline G2 & 3 & 0.741 & 0.852 & 0.800 \\
\hline G3 & 10 & 0.822 & 0.369 & 0.889 \\
\hline G4 & 4 & 0.896 & 0.813 & 0.898 \\
\hline G5 & 6 & 0.924 & 0.901 & 0.928 \\
\hline G6 & 5 & 0.861 & 0.732 & 0.931 \\
\hline
\end{tabular}

\subsection{Structural Model}

The Structural Equation Modeling (SEM) represents a multivariate statistical technique used to analyze the structural relations between the dependent and latent variables. Its greatest advantage is the possibility for multivariate analysis at one time.

Two types of variables are identified in the analysis i.e. endogenous - variables determined by the system or variables deriving from the models (representing an equivalent to a dependent variable), and exogenous - variables outside the models, meaning that their values are accepted as given (representing the equivalent to an independent variable). SEM tests and evaluates the relationships in a model using a combination of statistical data and qualitative causal assumptions. It can be used for the verification or development of hypotheses, or for the confirmative or research purposes. One of the great strengths of this type of modeling is the ability to create latent variables, variables that may not be measured directly but are assessed in the model based on other measured variables. These variables are 
actually grouping factors of certain measured variables. In order to develop a model of structural equations, the grouping of the initial measured variables by application of, for example, factor analysis, is performed beforehand.

Based on the conclusions drawn from the results of the statistical analysis, especially the factor analysis described in the previous text, and in order to verify the initial research hypotheses, the structural models for the analysis of risk in the examined SIPs were set. The models are presented in Figure 1.

The following correlations have been verified through the structural equation model (Figure 1a):

- The applied methods of the project risk assessment and analysis (G1) are positively related to the risk factors that affect SIP success (G2). The correlation level is 0.41 . It may therefore be concluded that the research hypothesis $\mathrm{H} 1$ has been verified.

- The applied methods of the project risk assessment and analysis (G1) are also positively related to the risk factors that affect SIP success (G3). The correlation level is 0.60 . Verification of the hypothesis $\mathrm{H} 2$.

- The risk factors affecting the overall project success (G2) are positively related to the achieved results of the project risk management (Q1). The correlation level is 0.32 . Verification of the hypothesis $\mathrm{H} 3$.

- The factors affecting the project risk management (G3) are also positively related to the achieved results of the project risk management (Q1). The correlation level is 0.37 . Verification of the hypothesis $\mathrm{H} 4$.

- The achieved results of the project risk management (Q1) are positively related to the success of SIP risk management $(\mathrm{Q} 2)$. The correlation level is 0.74 . Axiom A1.

The following correlations have also been verified (Figure 1b):

- The elements of the significance in the process of SIP control (G4) are positively related to the methods for evaluation and control of SIPs (G5), with the correlation level of 0.41 . Verification of the hypothesis $\mathrm{H} 5$.

- The methods for evaluation and control of SIPs (G5) are positively related to the criteria for the measuring of SIP success (G6), with 0.40 correlation. Verification of the hypothesis H6.

- Finally, the criterion for measuring the success of SIPs (G6) is directly related to the success of SIP management (Q2), with correlation level of 0.59. Axiom A2. 


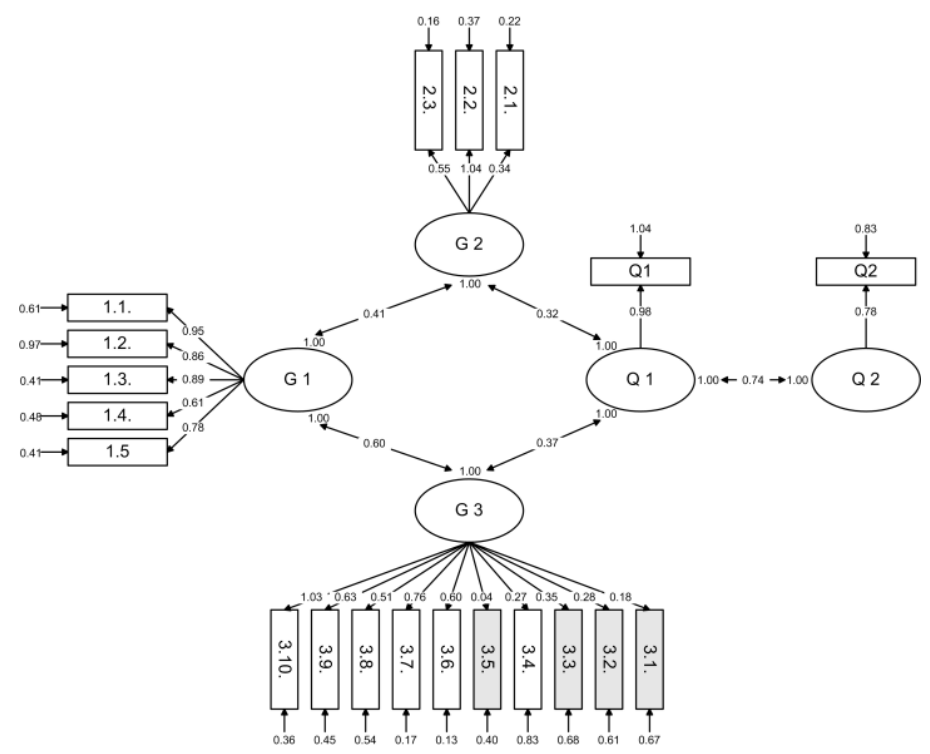

(a)

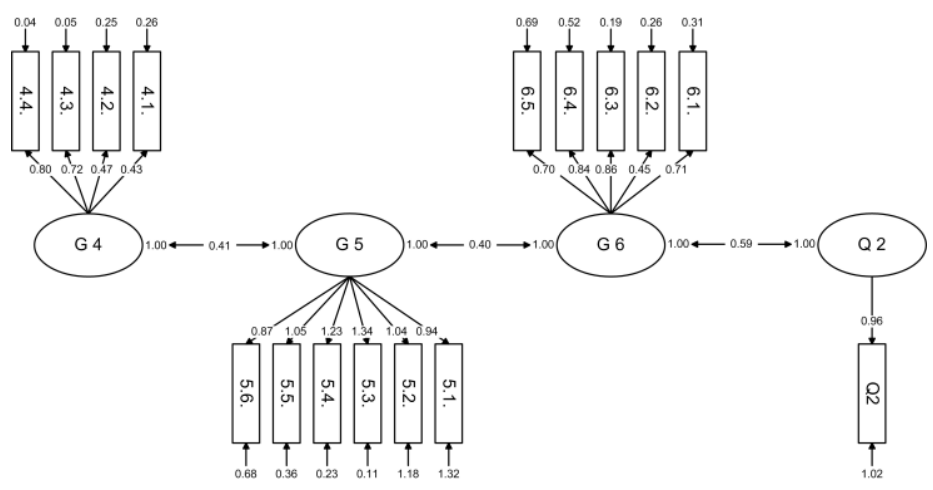

(b)

Figure 1

Structural models for the verification of the initial research hypotheses

Considering the existence of a strong positive direct correlation between the listed question groups, also proven in the form of combination of the direct and indirect correlations using SEM, it may be concluded that all of the hypotheses proposed in this research have been verified. The relationship between the two hypothetical models (Figure 1a and Figure 1b), may be established through a common key question, as present in both cases - the key question Q2. 


\subsection{Ranking the Importance of the Project Risks}

To assess the influence of the project types, based on the field of the company, and the position of employees in organizations related to the success on risk management of the SIPs, in addition to the success of the projects achieving predefined goals, the Multi-Criteria Decision Analysis (MCDA) was used [39]. The MCDA methodology was based on the PROMETHEE II technique sustained with the GAIA plane representation. Obtained MCDA results represent a comparison of the identified project risks in analyzed companies across different sectors. This way, it could be identified which of the risk factors are of largest influence on success of quality, time and cost management at SIPs [40, 41]. During the process of application of the PROMETHEE II methodology, the alternatives were ranked based on the values of their net flows, which represents a complex ranking procedure. Moreover, this method could use the DECISION LAB software, enabling graphical visualization of the obtained results in the form of the GAIA plane (Geometrical Analysis for Interactive Aid) [42].

The influence of the two demographic parameters (the project type and the position of the respondent in the organization) on the SIP risk management was applied to the methodology as well. The initial data used in the PROMETHEE procedure is presented in the Table 4 . The values in the Table 4 are presenting the average ranking of the individual groups of questions assessed by the employees which are involved in different SIPs in the SEE region, at different work place locations. For each work place, which is actually representing the position of the employee in the project team (top manager P1, middle management level P2, operational management level P3 and employee P4), given the researched project types (ICT (T1), I\&R (T2), civil construction works (T3), public sector (T4), scientific research work (T5) and else (T6)), the average ranking of the employees was calculated and presented in the Table 4.

Given that the PROMETHEE methodology includes the weight coefficient for each selected criterion, and as such is associated with certain decision functions, the results are presented in the Table 5. The weight coefficients can be described as raw indicators of relative importance of each selected criterion in the analysis. The entropic approach was used for the weights determination [43]. The Min/Max values were based on the type of the questions and their potential impact on the investigated factors.

The data presented in the Table 4 has been analyzed by using the software Decision Lab 2000. The results of the full ranking based on the PROMETHEE II method are presented in the Table 6 and the Figure 2. The visual presentation of obtained ranking is presented in the Figure 3. 
Table 4

Initial data used in the PROMETHEE multi criteria decision making analyses for the strategic investment projects (SIP)

\begin{tabular}{|l|c|c|c|c|c|c|c|c|}
\hline \multicolumn{1}{|c|}{ Criteria } & $\begin{array}{c}\text { Applied } \\
\text { method } \\
\text { s of } \\
\text { project } \\
\text { risk } \\
\text { assessm } \\
\text { ent and } \\
\text { analysis } \\
\text { (G1) }\end{array}$ & $\begin{array}{c}\text { Risk } \\
\text { tactors } \\
\text { affect } \\
\text { SIP } \\
\text { success } \\
\text { (G2) }\end{array}$ & $\begin{array}{c}\text { Risk } \\
\text { factors } \\
\text { that } \\
\text { affect } \\
\text { SIP } \\
\text { success } \\
\text { (G3) }\end{array}$ & $\begin{array}{c}\text { Elemen } \\
\text { ts of } \\
\text { signific } \\
\text { ance in } \\
\text { the } \\
\text { process } \\
\text { of SIP } \\
\text { control } \\
\text { (G4) }\end{array}$ & $\begin{array}{c}\text { Method } \\
\text { s for } \\
\text { evaluati } \\
\text { on and } \\
\text { control } \\
\text { of SIP } \\
\text { (G5) }\end{array}$ & $\begin{array}{c}\text { Main } \\
\text { criteria } \\
\text { for the } \\
\text { measur } \\
\text { ement } \\
\text { of SIP } \\
\text { success } \\
\text { (G6) }\end{array}$ & $\begin{array}{c}\text { Did } \\
\text { applied } \\
\text { manage } \\
\text { ment } \\
\text { method } \\
\text { give } \\
\text { good } \\
\text { results? } \\
\text { (Q1) }\end{array}$ & $\begin{array}{c}\text { Was the } \\
\text { SIP } \\
\text { manage } \\
\text { ment } \\
\text { success } \\
\text { ful? } \\
\text { (Q2) }\end{array}$ \\
\hline $\begin{array}{l}\text { ICT, Top manager / director } \\
\text { (T1P1) }\end{array}$ & 3.40 & 3.90 & 4.00 & 4.10 & 2.60 & 4.30 & 2.00 & 2.00 \\
\hline $\begin{array}{l}\text { ICT, Operational level of } \\
\text { management (T1P3) }\end{array}$ & 1.50 & 2.80 & 2.60 & 2.70 & 2.10 & 2.30 & 1.00 & 1.00 \\
\hline $\begin{array}{l}\text { R\&D, Top manager / director } \\
\text { (T2P1) }\end{array}$ & 3.10 & 3.70 & 3.60 & 4.40 & 3.60 & 3.80 & 2.00 & 2.00 \\
\hline R\&D, Employees (T2P4) & 2.60 & 4.10 & 3.80 & 4.10 & 2.90 & 4.80 & 2.00 & 2.00 \\
\hline $\begin{array}{l}\text { Construction, Middle } \\
\text { management (T3P2) }\end{array}$ & 2.70 & 4.20 & 4.20 & 4.00 & 3.80 & 4.50 & 2.00 & 2.00 \\
\hline $\begin{array}{l}\text { Public administration, Middle } \\
\text { management (T4P2) }\end{array}$ & 2.10 & 3.00 & 3.20 & 2.50 & 2.70 & 3.70 & 1.00 & 1.00 \\
\hline $\begin{array}{l}\text { Public administration, } \\
\text { Employees (T4P4) }\end{array}$ & 2.90 & 2.60 & 4.00 & 4.10 & 3.60 & 3.00 & 1.00 & 1.00 \\
\hline $\begin{array}{l}\text { Scientific-research, Middle } \\
\text { management (T5P2) }\end{array}$ & 2.20 & 4.00 & 4.20 & 3.90 & 1.60 & 4.20 & 1.00 & 1.00 \\
\hline $\begin{array}{l}\text { Scientific-research, Operational } \\
\text { level of management (T5P3) }\end{array}$ & 2.50 & 3.70 & 4.10 & 2.80 & 2.40 & 3.70 & 1.10 & 1.10 \\
\hline $\begin{array}{l}\text { Scientific-research, Employees } \\
\text { (T5P4) }\end{array}$ & 3.10 & 3.80 & 3.70 & 3.70 & 2.80 & 3.90 & 2.00 & 1.40 \\
\hline $\begin{array}{l}\text { Other, Top manager / director } \\
\text { (T6P1) }\end{array}$ & 2.40 & 3.50 & 3.80 & 3.30 & 2.30 & 3.90 & 1.30 & 1.30 \\
\hline $\begin{array}{l}\text { Other, Operational level of } \\
\text { management (T6P3) }\end{array}$ & 2.20 & 3.50 & 3.80 & 3.70 & 2.60 & 4.30 & 1.10 & 2.00 \\
\hline
\end{tabular}

Table 5

Preference functions and weight coefficient of criterions

\begin{tabular}{|l|l|l|l|l|l|l|l|l|}
\hline Criterion & G1 & G2 & G3 & G4 & G5 & G6 & Q1 & Q2 \\
\hline $\begin{array}{l}\text { Weight } \\
\text { coefficient }\end{array}$ & 0.1246 & 0.1235 & 0.1232 & 0.1240 & 0.1253 & 0.1241 & 0.1279 & 0.1275 \\
\hline $\begin{array}{l}\text { Preference } \\
\text { function }\end{array}$ & Level & Level & Level & Level & Level & Level & Level & Level \\
\hline Min/Max & MAX & MAX & MAX & MAX & MAX & MAX & MAX & MAX \\
\hline
\end{tabular}

Based on the results of the MCDA, presented in the Table 6 and the Figures 2 and 3 , it can be concluded that employees at both levels of research \& development projects (T2P1 and $\mathrm{T} 2 \mathrm{P} 4)$ are completely satisfied with the success of the project risks management as well as the success of the projects. This was also the opinion for the middle level managers of the civil works construction projects (T3P2). 
Conversely, the employees which strongly emphasized the negative outcomes from the project risk management they were involved in as well as the low success of the projects, belong to the operational level of managers at scientific/research projects (T5P3) and middle level managers in public institutions (T4P2). The lowest ranking of the investigated factors was obtained among the ICT projects upon opinion obtained from the operational level managers (T1P3).

The position of the considered alternatives (triangles) identifies the strengths and the weaknesses of the actions determining the criterions (rectangles), as presented in the Figure 3. The closest the alternative lies to the direction of the criterion vector, the alternative is ranked better from the point of this criterion [42]. This way, as presented in the GAIA plane (Figure 3) the criterions Q1, Q2 and G4 have largest influence on the ranking of the alternatives, based on their position towards the $p i$ vector - the decision stick (the red vector in the plane). In contrast, the criterions G2 and G6 have the lowest influence on their decisions, based on the position relative to the $p i$ vector.

Table 6

Results of complete ranking of the success in the risk management of the strategic investment projects based on the opinions of employees at different project team positions

\begin{tabular}{|l|l|l|l|l|}
\hline Rank & Alternatives & $\Phi^{+}$ & $\Phi^{-}$ & $\Phi$ \\
\hline 1 & T3P2 & 0.2789 & 0.0057 & 0.2733 \\
\hline 2 & T2P1 & 0.2679 & 0.0225 & 0.2454 \\
\hline 3 & T1P1 & 0.2223 & 0.0171 & 0.2053 \\
\hline 4 & T2P4 & 0.2278 & 0.0227 & 0.2051 \\
\hline 5 & T5P4 & 0.1480 & 0.0630 & 0.0850 \\
\hline 6 & T6P3 & 0.1195 & 0.0857 & 0.0338 \\
\hline 7 & T4P4 & 0.1246 & 0.1762 & -0.0516 \\
\hline 8 & T5P2 & 0.0844 & 0.1660 & -0.0816 \\
\hline 9 & T6P1 & 0.0620 & 0.1541 & -0.0922 \\
\hline 10 & T5P3 & 0.0507 & 0.1654 & -0.1147 \\
\hline 11 & T4P2 & 0.0339 & 0.2834 & -0.2494 \\
\hline 12 & T1P3 & 0.0000 & 0.4584 & -0.4584 \\
\hline
\end{tabular}

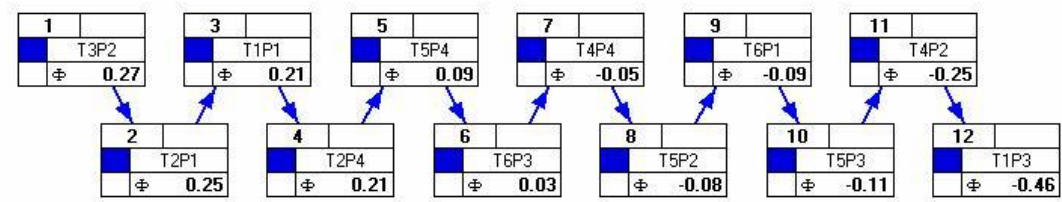

Figure 2

Results of the complete ranking of the success of the strategic investment project risk management, based on the PROMETHEE II methodology 


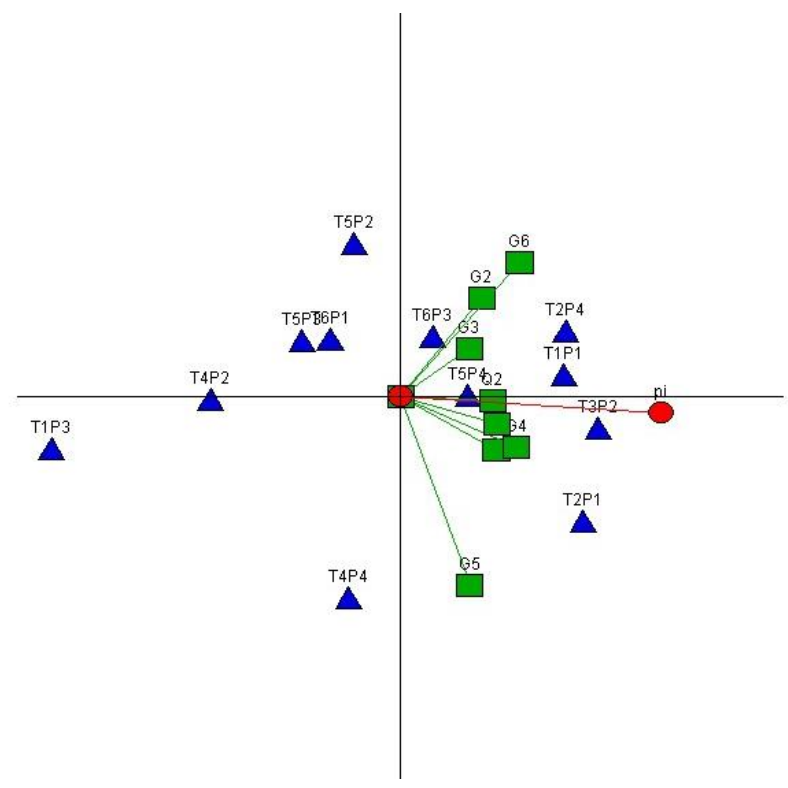

Figure 3

Graphic presentation at GAIA plane for ranking of the success of the risk management of the strategic investment projects

\section{Conclusion}

Strategic investment projects represent the very foundation of economic development and the development of Society, in general. Detailed analysis and approaches to the management of every single element of these types of projects is required given their level of significance. The potential risks and their adverse effects, represent a particularly weighty part of that process, especially the possibility to eliminate or minimize them or respond in a suitable way. The statistical analysis of the data collected through a survey of employees in 311 companies and organizations within the area of SEE, dealing with SIP management within their operations, leads to the following conclusions. The initial questions in the questionnaire, as well as the initial hypothetical framework of the research, have been defined based on the analysis of the available literature in the field. Accordingly, six research hypotheses were proposed based on the relation between application of the methods for risk analysis and identified risk factors influencing the SIPs success in SEE.

Conducted factor analysis, according to the question groups in the initial questionnaire, indicated that subgroups should be formed within certain groups, whereas certain questions should be eliminated from the further analysis. The final groups of questions, classified by factors, were used to develop a structural model, used for verification of the previously set hypothetical framework. 
Based on the formed structural model for risk analysis of SIPs, it can be concluded that the hypotheses have been verified. The obtained results could be of use for the risk analysis and the strategic project management, connecting the identified project risks with applicable methods for risk analysis, in the real life project management practice. Finally, the obtained results, presented in this paper, represent a solid foundation for the continuation of the research and the development of a final measurement instrument and model of SIP risk management.

We suggest that future research should apply the GLM multivariate procedure and focus on the influence of the most significant demographic characteristics of the projects (project type, project duration, project budget and type of project management), as well as, the different methodologies for risk management of the projects, on the overall SIP success. Also, additional research endeavors should target new and larger samples of respondents.

\section{References}

[1] Asrilhant, B., Meadows, M., Dyson, R., Techniques to Support Successful Strategic Project Management in the UK Upstream Oil and Gas Sector, European Management Journal, 24(2-3) (2006) pp. 214-225

[2] Schoemaker, P. J. H., How to Link Strategic Vision to Core Capabilities, Sloan Management Review, 34(1) (1992) pp. 67-72

[3] Buckley, A., International Investment: Value Creation and Appraisal, Copenhagen Business School, Denmark, 1998

[4] Foss, N. J., Resources and Strategy: Problems, Open Issues, and Ways Ahead, In Resources, Firms and Strategies: A Reader in the Resource-based Perspective, ed. N. J. Foss, pp. 345-365. Oxford University Press, Oxford, 1997

[5] Turner, R., Projects and Project Management, In Gower Handbook of Project Management, (eds) J. R. Turner and S. J. Simister ( $3^{\text {rd }}$ ed.) pp. 6576, Spring, UK, 2000

[6] Brook, J. W., Pagnanelli, F., Integrating Sustainability into Innovation Project Portfolio Management - A Strategic Perspective, Journal of Engineering and Technology Management, 34 (2014) pp. 46-62

[7] Huang, Y. C., Ma, R., Lee, K. W., Exploitative Learning in Project Teams: Do Cognitive Capability and Strategic Orientations Act as Moderator Variables? International Journal of Project Management, 33 (2015) pp. 760-771

[8] Mooraj, S., Oyon, D., Hostettler, D., The Balanced Scorecard: a Necessary Good or an Unnecessary Evil? European Management Journal, 17(5) (2009) pp. 481-491 
[9] Project Management Institute (PMI), A Guide to the Project Management Body of Knowledge $\left(\mathrm{PMBOK}^{\circledR}\right.$ Guide) - Fifth edition, Newtown Square, PA: Author, 2013

[10] Kerzner, H., Project Management: A Systems Approach to Planning, Scheduling and Control, John Wiley \& Sons, Inc., Hoboken, New Jersey, 2009

[11] Kumar, M., Gregory, M., An Exploration of Risk Management in Global Industrial Investment, Risk Management, 15(4) (2013) pp. 272-300

[12] Marmier, F., Deniaud, I. F., Gourc, D., Strategic Decision-Making in NPD Projects according to Risk: Application to Satellites Design Projects, Computers in Industry, 65 (2014) pp. 1107-1114

[13] Hussein, B. A., Klakegg, O. J., Measuring the Impact of Risk Factors Associated with Project Success Criteria in Early Phase, Procedia - Social and Behavioral Sciences, 119 (2014) pp. 711-718

[14] Peixoto, J., Tereso, A., Fernandes, G., Almeida, R., Project Risk Management Methodology: A Case Study of an Electric Energy Organization, Procedia Technology, 16 (2014) pp. 1096-1105

[15] Carvalho, M. M., Patah, L. A., Bido, D. S., Project Management and its Effects on Project Success: Cross-Country and Cross-Industry Comparisons, International Journal of Project Management, 33 (2015) pp. $1509-1522$

[16] Enescu, M., Enescu, M., Tudorescu, N., Points of View Regarding the Evaluation of Decisional Factors in Risk Management Associated to Large Combustion Plants, Procedia Economics and Finance, 16 (2014) pp. 110114

[17] Marcelino-Sádaba, S., Pérez-Ezcurdia, A., Lazcano, A. M. E., Villanueva, P., Project Risk Management Methodology for Small Firms, International Journal of Project Management, 32 (2014) pp. 327-340

[18] Ameyaw, E. E., Chan, A. P. C., Evaluation and Ranking of Risk Factors in Public-Private Partnership Water Supply Projects in Developing Countries using Fuzzy Synthetic Evaluation Approach, Expert Systems with Applications, 42 (2015) pp. 5102-5116

[19] Kutsch, E., Hall, M., The Rational Choice of not Applying Project Risk Management in Information Technology Projects, Project Management Journal, 40(3) (2009) pp. 72-81

[20] Espinoza, R. D., Separating Project Risk from the Time Value of Money: A Step toward Integration of Risk Management and Valuation of Infrastructure Investments, International Journal of Project Management, 32 (2014) pp. 1056-1072 
[21] Rodrigues-da-Silva, L. H., Crispim, J. A., The Project Risk Management Process, a Preliminary Study, Procedia Technology, 16 (2014) pp. 943-949

[22] Hwang, B.-G., Zhao, X., Gay, M. J. S., Public Private Partnership Projects in Singapore: Factors, Critical Risks and Preferred Risk Allocation from the Perspective of Contractors, International Journal of Project Management, 31 (2013) pp. 424-433

[23] Ihuah, P. W., Kakulu, I. I., Eaton, D., A Review of Critical Project Management Success Factors (CPMSF) for Sustainable Social Housing in Nigeria, International Journal of Sustainable Built Environment, 3 (2014) pp. 62-71

[24] Shrivastava, S. V., Rathod, U., Categorization of Risk Factors for Distributed Agile Projects, Information and Software Technology, 58 (2015) pp. 373-387

[25] Lončar, D., Applicative Model for Appraisal of Investment Projects Based on Real Options Methodology, Serbian Journal of Management, 6(2) (2011) pp. 269-282

[26] Pandremmenou, H., Sirakoulis, K., Blanas, N., Success Factors in the Management of Investment Projects: A Case Study in the Region of Thessaly, Procedia - Social and Behavioral Sciences, 74 (2013) pp. 438447

[27] Kiliç, M., Kaya, I., Investment Project Evaluation by a Decision Making Methodology Based on Type-2 Fuzzy Sets., Applied Soft Computing, 27 (2015) pp. 399-410

[28] Drury-Grogan, M. L., Performance on Agile Teams: Relating Iteration Objectives and Critical Decisions to Project Management Success Factors, Information and Software Technology, 56 (2014) pp. 506-515

[29] Lappe, M., Spang, K., Investments in Project Management are Profitable: A Case Study-based Analysis of the Relationship between the Costs and Benefits of Project Management, International Journal of Project Management, 32 (2014) pp. 603-612

[30] Todorović, M. Lj., Petrović, D. Č., Mihić, M. M., Obradović, V. Lj., Bushuyev, S. D., Project Success Analysis Framework: A Knowledgebased Approach in Project Management, International Journal of Project Management, 33 (2015) pp. 772-783

[31] Liu, S., Wang, L., Understanding the Impact of Risks on Performance in Internal and Outsourced Information Technology Projects: The Role of Strategic Importance, International Journal of Project Management, 32 (2014) pp. 1494-1510 
[32] Junkes, M. B., Tereso, A. P., Afonso, P. S. L. P., The Importance of Risk Assessment in the Context of Investment Project Management: a Case Study, Procedia Computer Science, 64 (2015) pp. 902-910

[33] Davis, K., A Method to Measure Success Dimensions Relating to Individual Stakeholder Groups, International Journal of Project Management, 34 (2016) pp. 480-493

[34] Kaiser, H. F., An Index of Factorial Simplicity, Psychometrika, 39 (1974) pp. 31-36

[35] Hair, J. F., Black, W. C., Babin, B. J., Anderson, R. E., Tatham, R. L., Multivariate Data Analysis, $6^{\text {th }}$ Edition, Pearson Prentice Hall, Upper Saddle River, NJ, 2006

[36] Gorsuch, R. L., Factor Analysis, Hillsdale, NJ: Lawrence Erlbaum, 1983

[37] Cronbach, L. J., Coefficient Alpha and the Internal Structure of Tests, Psychometrika, 16 (1951) pp. 297-334

[38] Nunnally, JM., Psychometric Theory, third ed. McGraw-Hill, New York, 1994

[39] Roy, B., Vincke, P., Multicriteria Analyses: Survey and New Directions, European journal of operational research, 8 (3) (1981) pp. 207-218

[40] Csala, V., Szalay, T., Farkas, B., Markos, S., Application Benchmark of Three Micro Hole Machining Processes for Manufacturing the Nozzle of a Medical Water Jet Machine, Acta Polytechnica Hungarica, 12(2) (2015) pp. 53-69

[41] Živković, Ž., Nikolić, Dj., Djordjević, P., Mihajlović, I., Savić, M., Analytical Network Process in the Framework of SWOT Analysis for Strategic Decision Making (Case Study: Technical Faculty in Bor, University of Belgrade, Serbia), Acta Polytechnica Hungarica, 12(7) (2015) pp. 199-216

[42] Brans, J. P., Mareschal, B., The PROMCALC \& GAIA Decision Support System for Multicriteria Decision Aid, Decision Support Systems, 12 (1994) pp. 297-310

[43] Zhi-hong, Z., Yi, Y., Jing-nan, S., Entropy Method for Determination of Weight of Evaluating Indicators in Fuzzy Synthetic Evaluation for Water Quality Assessment, Journal of Environmental Sciences, 18 (2006) pp. 1020-1023 
Appendix 1

Results of the descriptive statistics of answers to the questionnaire questions

\begin{tabular}{|c|c|c|c|c|c|c|}
\hline & \multirow{2}{*}{ N } & \multirow{2}{*}{$\begin{array}{l}\text { Range } \\
\text { Statistic }\end{array}$} & \multicolumn{2}{|c|}{ Mean } & \multirow{2}{*}{$\begin{array}{c}\text { Std. } \\
\text { Deviation } \\
\text { Statistic }\end{array}$} & \multirow{2}{*}{$\begin{array}{c}\text { Var. } \\
\text { Statistic }\end{array}$} \\
\hline & & & Statistic & $\begin{array}{l}\text { Std. } \\
\text { Error }\end{array}$ & & \\
\hline $\begin{array}{l}\text { 1.1. Questionnaire is used as a method } \\
\text { for risk analysis and assessment. }\end{array}$ & 311 & 4 & 2.97 & .143 & 1.227 & 1.506 \\
\hline $\begin{array}{l}\text { 1.2. Sensitivity analysis is used as a } \\
\text { method for risk analysis and } \\
\text { assessment. }\end{array}$ & 311 & 3 & 2.66 & .152 & 1.306 & 1.706 \\
\hline $\begin{array}{l}\text { 1.3. Probability analysis is used as a } \\
\text { method for risk analysis and } \\
\text { assessment. }\end{array}$ & 311 & 3 & 2.55 & .128 & 1.100 & 1.209 \\
\hline $\begin{array}{l}\text { 1.4. Decision tree is used as a method } \\
\text { for risk analysis and assessment. }\end{array}$ & 311 & 3 & 2.43 & .107 & .923 & .852 \\
\hline $\begin{array}{l}\text { 1.5. The simulation method is used as a } \\
\text { method for risk analysis and } \\
\text { assessment. }\end{array}$ & 311 & 4 & 2.28 & .118 & 1.014 & 1.028 \\
\hline $\begin{array}{l}\text { 1.6. Brainstorming is used as a method } \\
\text { for risk analysis and assessment. }\end{array}$ & 311 & 4 & 2.49 & .152 & 1.306 & 1.705 \\
\hline $\begin{array}{l}\text { 1.7. The Delphi method is used as a } \\
\text { method for risk analysis and } \\
\text { assessment. }\end{array}$ & 311 & 4 & 2.84 & .143 & 1.228 & 1.508 \\
\hline $\begin{array}{l}\text { 1.8. WBS is used as a method for risk } \\
\text { analysis and assessment. }\end{array}$ & 311 & 3 & 2.08 & .129 & 1.107 & 1.226 \\
\hline $\begin{array}{l}\text { 2.1. Potential loss as a risk factor affects } \\
\text { the project success. }\end{array}$ & 311 & 2 & 3.54 & .067 & .578 & .334 \\
\hline $\begin{array}{l}\text { 2.2. Market risk as a risk factor affects } \\
\text { the project success. }\end{array}$ & 311 & 4 & 3.27 & .140 & 1.208 & 1.460 \\
\hline $\begin{array}{l}\text { 2.3. Foreign exchange risk as a risk } \\
\text { factor affects the project success. }\end{array}$ & 311 & 2 & 3.32 & .080 & .685 & .469 \\
\hline $\begin{array}{l}\text { 2.4. Cost assessment risk as a risk factor } \\
\text { affects the project success. }\end{array}$ & 311 & 3 & 3.51 & .082 & .707 & .500 \\
\hline $\begin{array}{l}\text { 2.5. Human resource as a risk factor } \\
\text { affects the project success. }\end{array}$ & 311 & 2 & 3.89 & .083 & .713 & .509 \\
\hline $\begin{array}{l}\text { 3.1. The probability of the occurrence of } \\
\text { a risk event is a significant factor for } \\
\text { risk management. }\end{array}$ & 311 & 4 & 3.76 & .098 & .841 & .707 \\
\hline $\begin{array}{l}\text { 3.2. The frequency of risk events is a } \\
\text { significant factor for risk management. }\end{array}$ & 311 & 4 & 3.68 & .096 & .829 & .688 \\
\hline $\begin{array}{l}\text { 3.3. The connection between different } \\
\text { risk events is a significant factor for risk } \\
\text { management. }\end{array}$ & 311 & 4 & 3.55 & .104 & .894 & .798 \\
\hline $\begin{array}{l}\text { 3.4. Potential loss is a significant factor } \\
\text { for risk management. }\end{array}$ & 311 & 3 & 3.97 & .110 & .950 & .903 \\
\hline $\begin{array}{l}\text { 3.5. Timeline risk is a significant factor } \\
\text { for risk management. }\end{array}$ & 311 & 2 & 3.70 & .074 & .635 & .404 \\
\hline $\begin{array}{l}\text { 3.6. Cost assessment risk is a significant } \\
\text { factor for risk management. }\end{array}$ & 311 & 3 & 3.84 & .082 & .703 & .494 \\
\hline $\begin{array}{l}\text { 3.7. Financing risk is a significant factor } \\
\text { for risk management. }\end{array}$ & 311 & 4 & 3.73 & .101 & .865 & .748 \\
\hline $\begin{array}{l}\text { 3.8. Market risk is a significant factor } \\
\text { for risk management. }\end{array}$ & 311 & 4 & 3.53 & .104 & .895 & .801 \\
\hline $\begin{array}{l}\text { 3.9. Foreign exchange risk is a } \\
\text { significant factor for risk management. }\end{array}$ & 311 & 4 & 3.20 & .107 & .921 & .849 \\
\hline
\end{tabular}




\begin{tabular}{|c|c|c|c|c|c|c|}
\hline $\begin{array}{l}\text { 3.10. The human factor is a significant } \\
\text { factor for risk management. }\end{array}$ & 311 & 4 & 3.72 & .138 & 1.188 & 1.412 \\
\hline $\begin{array}{l}\text { 4.1. Planned budget is a significant } \\
\text { element for project control and } \\
\text { evaluation. }\end{array}$ & 311 & 2 & 4.27 & .078 & .668 & .447 \\
\hline $\begin{array}{l}\text { 4.2. Available resources are a } \\
\text { significant element for project control } \\
\text { and evaluation. }\end{array}$ & 311 & 2 & 4.31 & .079 & .681 & .464 \\
\hline $\begin{array}{l}\text { 4.3. Project team capacity is a } \\
\text { significant element for project control } \\
\text { and evaluation. }\end{array}$ & 311 & 2 & 4.28 & .087 & .750 & .562 \\
\hline $\begin{array}{l}\text { 4.4. Project manager knowledge and } \\
\text { skills are a significant element for } \\
\text { project control and evaluation. }\end{array}$ & 311 & 3 & 4.19 & .096 & .822 & .676 \\
\hline $\begin{array}{l}\text { 4.5. Planned time of project } \\
\text { implementation is a significant element } \\
\text { for project control and evaluation. }\end{array}$ & 311 & 2 & 4.16 & .072 & .620 & .384 \\
\hline $\begin{array}{l}\text { 5.1. WBS is used as a method for SIP* } \\
\text { management. }\end{array}$ & 311 & 4 & 2.89 & .173 & 1.486 & 2.207 \\
\hline $\begin{array}{l}\text { 5.2. Milestone is used as a method for } \\
\text { SIP management. }\end{array}$ & 311 & 4 & 2.85 & .175 & 1.505 & 2.265 \\
\hline $\begin{array}{l}\text { 5.3. Organization methods are used for } \\
\text { SIP management. }\end{array}$ & 311 & 4 & 3.32 & .160 & 1.376 & 1.893 \\
\hline $\begin{array}{l}\text { 5.4. Cost assessment methods are used } \\
\text { for SIP management. }\end{array}$ & 311 & 4 & 3.68 & .153 & 1.315 & 1.729 \\
\hline $\begin{array}{l}\text { 5.5. The Gantt chart is used as a method } \\
\text { for SIP management. }\end{array}$ & 311 & 4 & 3.58 & .140 & 1.205 & 1.452 \\
\hline $\begin{array}{l}\text { 5.6. Network planning techniques are } \\
\text { used as methods for SIP management. }\end{array}$ & 311 & 4 & 2.85 & .140 & 1.201 & 1.443 \\
\hline $\begin{array}{l}\text { 6.1. Client satisfaction is the main } \\
\text { criterion for project success } \\
\text { measurement. }\end{array}$ & 311 & 2 & 4.15 & .105 & .902 & .813 \\
\hline $\begin{array}{l}\text { 6.2. Planned time of implementation is } \\
\text { the main criterion for project success } \\
\text { measurement. }\end{array}$ & 311 & 2 & 3.81 & .079 & .676 & .457 \\
\hline $\begin{array}{l}\text { 6.3. Planned budget is the main criterion } \\
\text { for project success measurement. }\end{array}$ & 311 & 3 & 3.92 & .112 & .962 & .925 \\
\hline $\begin{array}{l}\text { 6.4. Project quality is the main criterion } \\
\text { for project success measurement. }\end{array}$ & 311 & 4 & 3.92 & .129 & 1.107 & 1.226 \\
\hline $\begin{array}{l}6.5 \text {. The achievement of other } \\
\text { objectives is the main criterion for } \\
\text { project success measurement. }\end{array}$ & 311 & 4 & 3.55 & .126 & 1.087 & 1.182 \\
\hline $\begin{array}{l}\text { 6.6. Top management satisfaction is the } \\
\text { main criterion for project success } \\
\text { measurement. }\end{array}$ & 311 & 2 & 3.55 & .077 & .665 & .442 \\
\hline $\begin{array}{l}* \mathrm{Q} 1 \text { Has the methodology used for } \\
\text { project risk management provided good } \\
\text { results? }\end{array}$ & 311 & 2 & 1.32 & .110 & .952 & .907 \\
\hline $\begin{array}{l}* \mathrm{Q} 2 \text { Has SIP management in your } \\
\text { organization been successful? }\end{array}$ & 311 & 2 & 1.32 & .110 & .952 & .907 \\
\hline
\end{tabular}

* SIP - Strategic Investment Project; ** Questions Q1 and Q2 are questions with a dichotomous character (yes/no questions). The answer YES was ranked with a rating of 2 and $\mathrm{NO}$ was ranked with a 0 rating when the results were processed. 